\title{
A Systematic Literature on Application of Transit Oriented Development
}

\author{
Ar. Deepshikha Jain, Ekta Singh, Rashmi Ashtt
}

\begin{abstract}
Transit oriented development (TOD) has quickly developed as a well-known urban developing approach all around the world to achieve a spatial economic transport interaction. TOD does not only relate to mass transit, but it is a strategy to decongest nodal, major points, arteries of the city by making people walk, use public transport, in order to make city environmentally sustainable. Indian cities are fronting major predicament under the sphere of mobility in urban development for which smart cities concept TOD in developing and big countries like India. Hence, this paper will be majorly focusing on presentation of a methodical literature assessment. Though, TOD as a policy is envisaged to have a significant positive impact in mitigating issues at urban scale but there are variety of attributes and indicators that impact the applicability of (SLR) that targets the consolidated knowledge on Transit Oriented Development, analyze the parameters for the successful TOD's all over the world and provide steps for further exploration in Indian context. The corpus analysis of 102 articles and reports leading to the most significant research offerings on TOD acting as the essential pillar in the development is researched such that these results could be utilized for further research.
\end{abstract}

Keywords: Transit oriented development, systematic literature review, TOD parameters, sustainable development, pedestrian connectivity, accessibility, public transport, NMT (Nonmotorized transport), congestion, Indian cities, etc.

\section{INTRODUCTION}

Urbanization is a fundamental constituent of economic growth and rate of urbanization is rising universally. Modern urban time has formed an innovative environment that depends deeply on inadequate easily available resources. Due to increase in urbanization, a wide range of space is required for habitation which has challenged growing cities to become ecological. Since, conurbations are determined by its transportation system and almost all cities are developed on road based transport system. This has resulted side- effects like those of urban sprawl, increase in pollution levels, degradation at immune levels, etc. Hence, ities are required to take steps to make transport system Similarly, Figure 2 explains the disastrous decrease in the interest of Indians authors since 2006 on the topic "Transit As Figure 1 explains the decrement in the interest of authors and practitioners all over the world starting from the year 2004 which declares the rationale of the study in the present years.

Revised Manuscript Received on February 05, 2020.

* Correspondence Author

Ar. Deepshikha Jain*, Associate Professor at Hindu School of Architecture, Sonepat.

Ekta Singh, Director, Amity School of Design, Amity University Uttar Pradesh.

Rashmi Ashtt, Director of Hindu College of Design, Architecture and Planning, Delhi NCR

(c) The Authors. Published by Blue Eyes Intelligence Engineering and Sciences Publication (BEIESP). This is an open access article under the CC BY-NC-ND license (http://creativecommons.org/licenses/by-nc-nd/4.0/)
Oriented Development" over the time. Thus, there is a lot need to study this topic in Indian context as this has been majorly worked by United States only. more sustainable such that reduction in pollution, energy consumption, and congestion could be achieved for which Transit Oriented Development (TOD) acting as the best tool aiming in developing the habit of using public transport by integrating land use and transport systems finally making cities more livable and sustainable.

Therefore, this paper strives to conduct a systematic literature evaluation on the application of Transit Oriented Development (TOD), such that to identify the lack of information of various aspects of TOD in growing cities. Gathering information from 102 papers and reports for the period of 1992 to 2017,a summary of the vital issues as well as the growth over time is identified and even assessment of the key indicators are employed.

The term Transit Oriented Development has been diversely discussed by several authors differently and thus universally accepted definition has not been accredited till yet. As Singh et. al in mentioned that understanding TOD varies with the deliberate intend of TOD vary whereas; evaluation and assessment of TOD are also varies. Extensively known 3D concept (Density, Diversity and Design) and measured as a vital feature in assessing TOD planning is given by Cervero in 1997. In the same way, Calthrope (1993) highlights the substantial characteristics particularly the walk able atmosphere and a set of six performance criteria e.g. location, efficiency, value recapture, livability, financial returns, choice of lifestyle and efficient land use pattern was given by Belzer in 2002 condemning a good number of TOD.

\section{INTEREST FOR TRANSIT ORIENTED DEVELOPMENT BY VARIOUS AUTHORS}

According to the Google Trends, interest by various authors and practitioners is shown through the graphs below, by how often the topic is been searched by the people. 


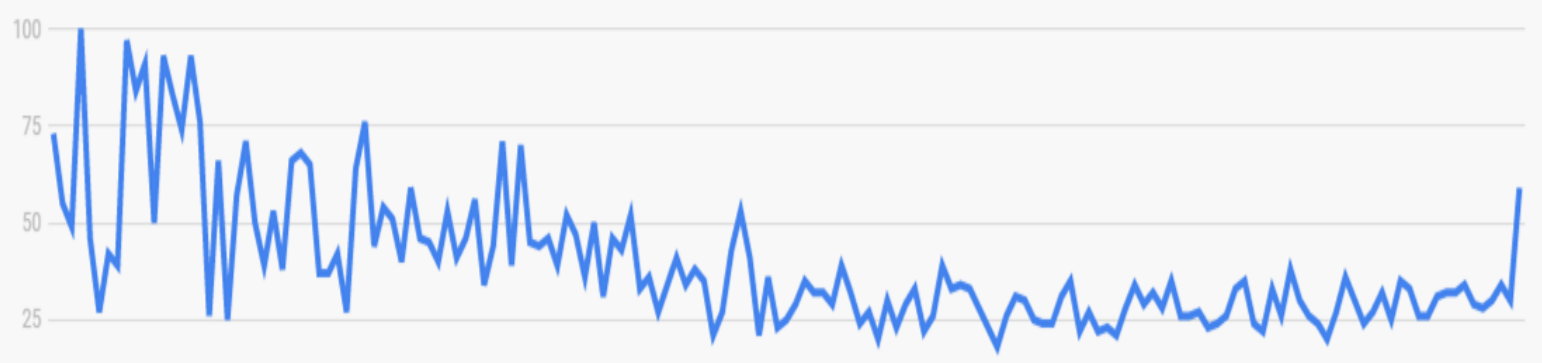

$\operatorname{Jan} 1,2004 \quad \operatorname{Jan} 1,2008 \quad \operatorname{Jan} 1,2012 \quad \operatorname{Jan} 1,2016$

Figure 1. Worldwide interest on the topic "Transit Oriented Development" over time. Source:

https://trends.google.co.in/trends/explore?date=all\&q=Transit\%20oriented\%20development, 4 April, 2017 at 1:57 AM.

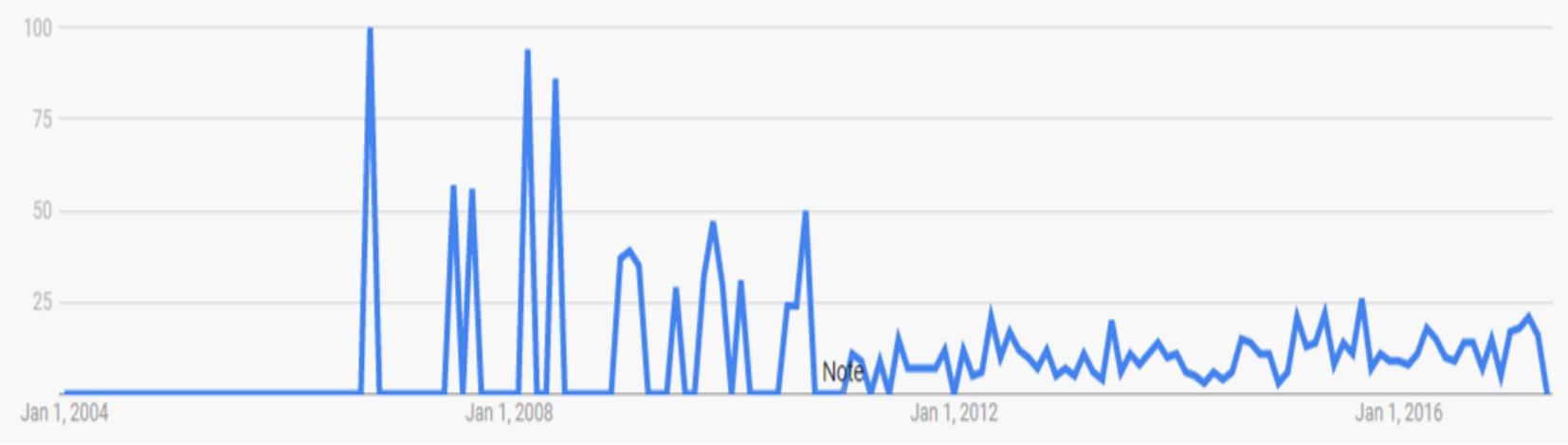

Figure 2. Interest on the topic "Transit Oriented Development" over time in India.

Source: https://trends.google.co.in/trends/explore?date=all\&q=Transit\%20oriented\%20development, 4 April, 2017 at 1:57 AM.

\section{OBJECTIVES OF THE RESEARCH}

It is the literature regarding application of transit oriented development, assessing the different focuses and different subjects of investigation. Some papers explicitly focused typically on the matter, whereas others are less focused and has discussed several topics at once. For illustration, Ghim Ping ONG et. Al (2010)examined various options which can be used by transportation and urban development agencies for promoting sustainability. Monyrath KOV et. al (2011) developed analytical model for determining optimal frequency for urban bus transit and Nguyen Quang Minh et. al (2011) helped in enhancing the quality of life by protecting the living environment for the residents by developing a planning concept of new traffic- and- service. Since, no systematic analysis could be found for application TOD for growing cities, thus, the first research addressed in this paper is:

Q1.To identify essential subjects related to Transit Oriented Development and how those topics evolved?

The literature exposes exceptionally different methods of formulation and evolving solution for determining optimal frequency for urban bus transit by Hooke- Jeeves algorithm by Monyrath KOV et. all (2011) to classification of various levels of residential QOL indicators and socioeconomic groups in station and no station areas by Kazuki Akamura et. all (2016) to demonstrate the comparison of rail- based accessibility in urban areas to jobs concentrated around railway network by Enrica Papa and Luca Bertolini (2015).While visiting some papers it came to notice that some papers have most suitable approaches and methodologies offering the complete coverage to the topic. Therefore, the second research question is:

Q2.To identifies the methodology and parameters used for the application of TOD in urban areas all over the world.

While giving the multiplicity of topics and a range of research methodologies, the objective to understand the parameters for the assessment of the application of TOD in an area even also to discover the best path. Thus, the third research question arrives as:

\section{Q3.To understands the literature pertaining to TOD in Indian cities.}

Further, identifying the planned TOD's in Indian cities and even to identify the places where the concept of transit oriented development tis proposed and executed in India, so, that the most practical guidelines for future research could be categorized. Finally, the fourth research question comes out as:

Published By: 
Q4. To examine the papers that are instrumental in assessing the literature till now?

To counter the above question, a SLR was elected with a specific focus on application of transit oriented development and methods by which these can be implemented. First, the SLR, procedure, the classification of the papers and the analysis that led to the answering of the questions are discussed. Subsequent, the chief conclusions from the collected body of papers are reported, bifurcating the essential areas mentioned and thus, development with time. Following, sprouting the methodologies and parameters and planned cities in India.

\section{THE RESEARCH METHOD}

The SLR method has been selected for this study because of the nature of the research questions aiming at the latest developments, changes and the existing gaps in the scientific literature. A review earns the adjective "systematic" when the questions are clearly formulated, studies are relevantly identified, quality is appraised and finally, methodology is summarized. It also provides a protocol with detailed documentation by L. Alexendra et. all (2016).

This SLR has adopted a four- step protocol to find out a valid procedure such that it can be replicated by other researchers also.

\section{Step 1: Insertion/ Omission Criteria}

In the start, a preliminary list of the keywords and insertion criteria were acknowledged, and the application of transit oriented development was devised by the various synonyms (for e.g. sustainable transport, green TOD) in the keywords, creating the research all-inclusive. Moreover, the study focused on the documents published in journals and reports like transportation, urban planning, management and engineering science for the period 1992 to 2017. The starting year was selected because, however Peter Calthorpe in his publication "The New American Metropolis" in 1993, codified the concept of Transit-Oriented Development (TOD) and thus, the major push began around the year 1992.Conference proceedings and grey literature like technical report and works in progress is also included in corpus.

The exploration was started based on the criteria as per Table 1.Most of the publishers chosen for the research are Elsevier, Science Direct, Journal of Transport and Landuse, etc. were chosen for analysis. Whereas paper based on TOD and housing, property valuation, employment, economics, etc, are excluded. Each paper which leads to the disparity regarding insertion/ omission criteria was read completely until conformity was achieved. This lead to the final selection as accounted in Table 1 which resulted in the extraction of 65papers and reports. (Figure 3).

\section{Step 2: Selection based on title and omission criteria}

After reviewing the titles and omission of papers, 473 were selected to go for next step.

\section{Step 3: Selection based on reading abstracts/ contents}

Finally, after reading abstracts of papers and contents of reports 234 researches were selected, by removing the work out of the research scope from the corpus. Specifically, 239 researches that did not focus exactingly on transit oriented development rather focusing on health, financial planning, economical planning, social aspects, traffic engineering and many more were excluded.

Table 1. Insertion criteria for paper selection.

\section{Insertion Criteria Description}

\begin{tabular}{ll}
\hline Keywords & $\begin{array}{l}\text { Transit Oriented Development (TOD), Green TOD, Sustainable Transport, NMT, } \\
\text { indicators of TOD, Design parameters for a successful TOD }\end{array}$ \\
\hline Language & English \\
\hline Document Types & Articles and Reports \\
Source Types & Journals and Reports \\
\hline
\end{tabular}

Time Interval 1992-2017

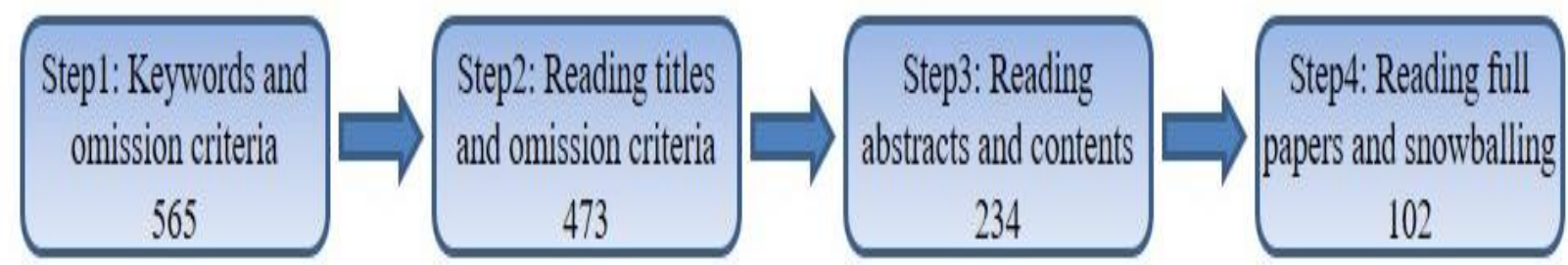

Figure 3. Systematic literature review results according to the selection procedure. 


\section{A Systematic Literature on Application of Transit Oriented Development}

Step 4: Selection based on full text and snow balling

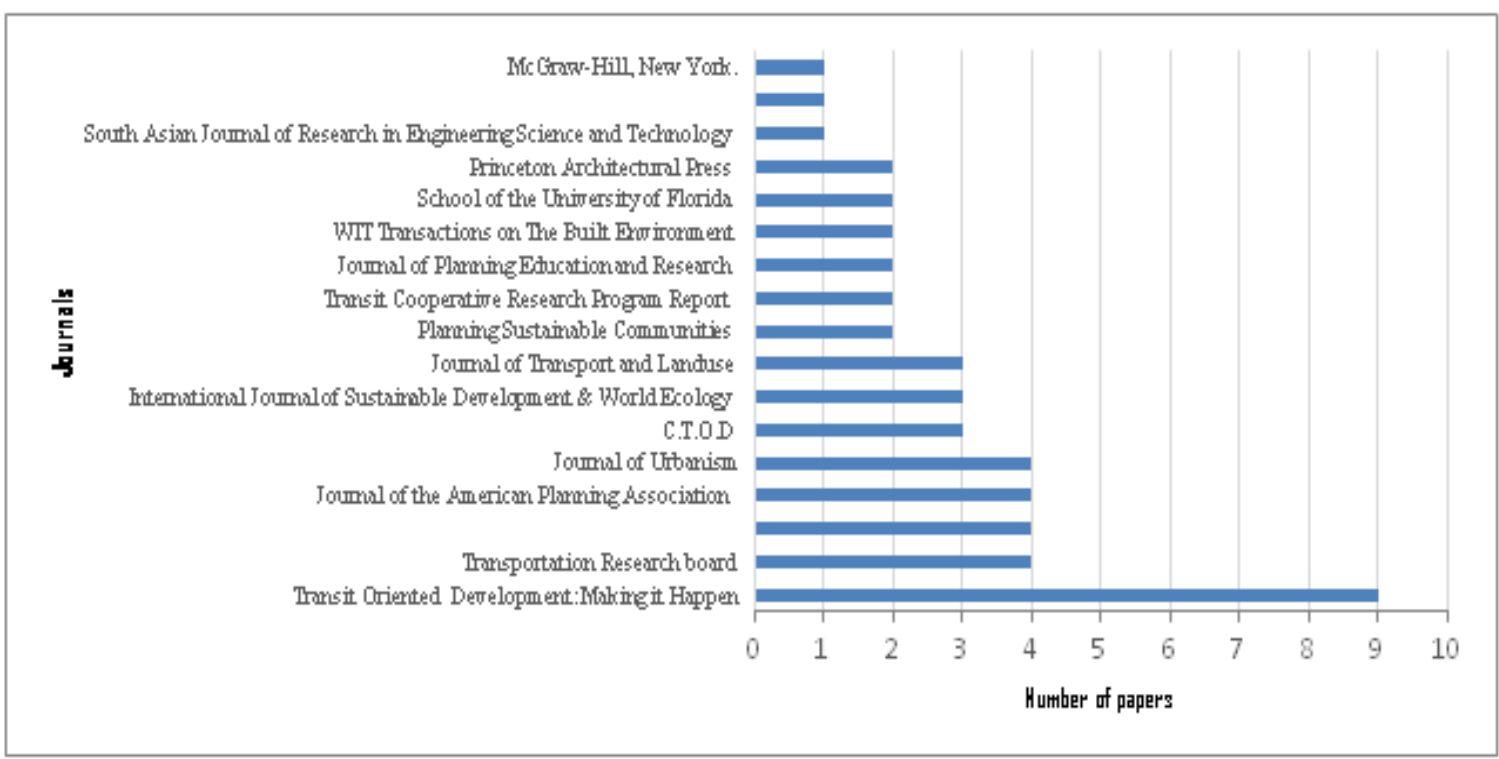

Figure 4. Papers bifurcated according to the period (year) of publication.

The final step of the procedure included the distillation of the list of selected research works. After reading the full versions of papers and reports, 141 were not in the exact scope of the research work i.e. parameters for the application of transit oriented development and hence, were excluded. After listing down the focused research works, the references of selected were checked i.e. backwards snowballing, and spotted the most cited papers at least more than five times. Finally, missing works are added in the corpus, leading to a final corpus of 102 researches.

The outcomes in terms of number of works are programmed according to the selection criteria in Figure3. Further for the answer of four research questions the main conclusion from the collected corpus of papers are accounted, distinguished according to the broad divisions of main topics addressed and their evolution over time were also accomplished to emphasize the strength of the progress of the SLR.

\section{ELOQUENTSCRUTINY OF THE CORPUS}

Figure 4 explains the bifurcation according to the year of publishing and it can be seen that despite of some variations in the considered time interval, a positive growth in the contributions regarding Transit oriented Development in the last ten years could be seen, finally authenticating the current significance of the subject.

The peak number of researches in this field can be seen in the last year i.e., 2016 partially due to the relevance and need of the subject in the present scenario and thus leading to the awareness regarding the concept of Transit Oriented Development among Planners, Demographists, Economists, etc. Since the scope of the topic ding a range of articles and report listed at the second stage, still a development can be analyzed where after 2 is very wide, thus, an extensive range of publications has been listed while going through the references. After exclu009 where 14 publications are found and with a growth of 12 publications in 2014and of 2016 has hit the highest point in special case of Transit Oriented Development confirming the rising trend of the publications on the topic through the years.

Altogether, the corpus includes a categorization of 55different journals and reports (Figure 5) where there is no overriding publisher. Further, this bifurcation is categorized under broad divisions as seen in Figure 6.

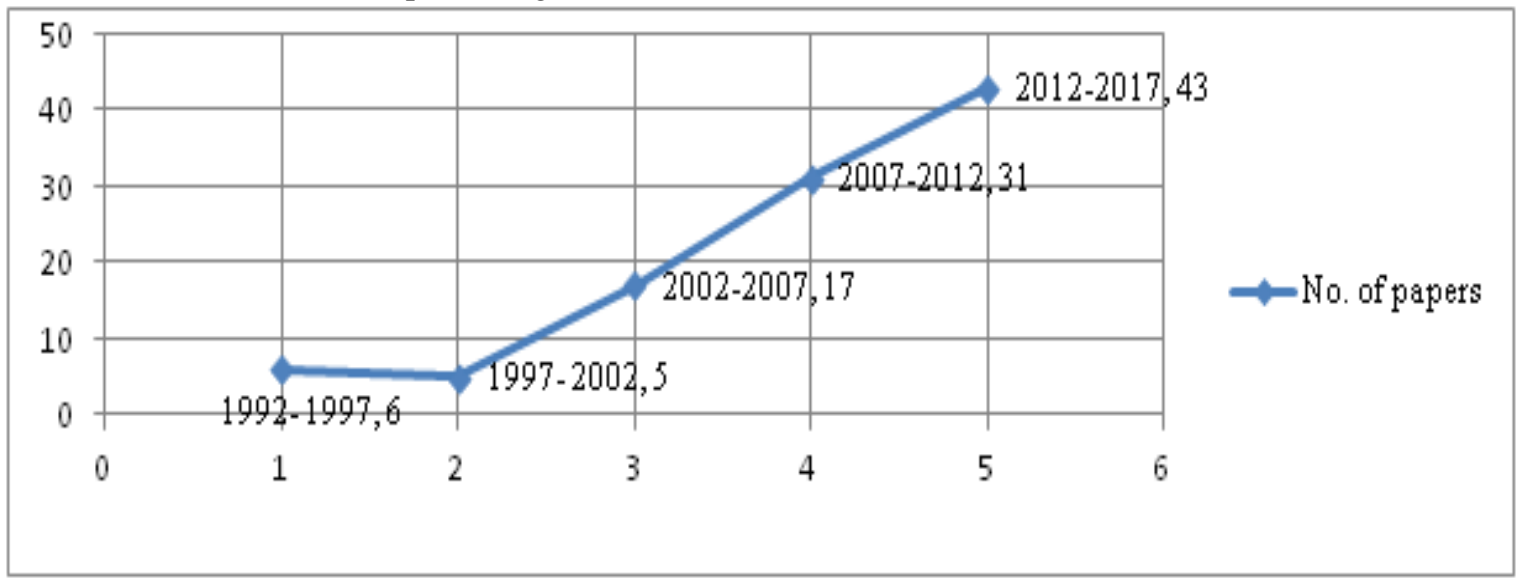

Figure 5. Quantity of papers from each journal in the corpus. 


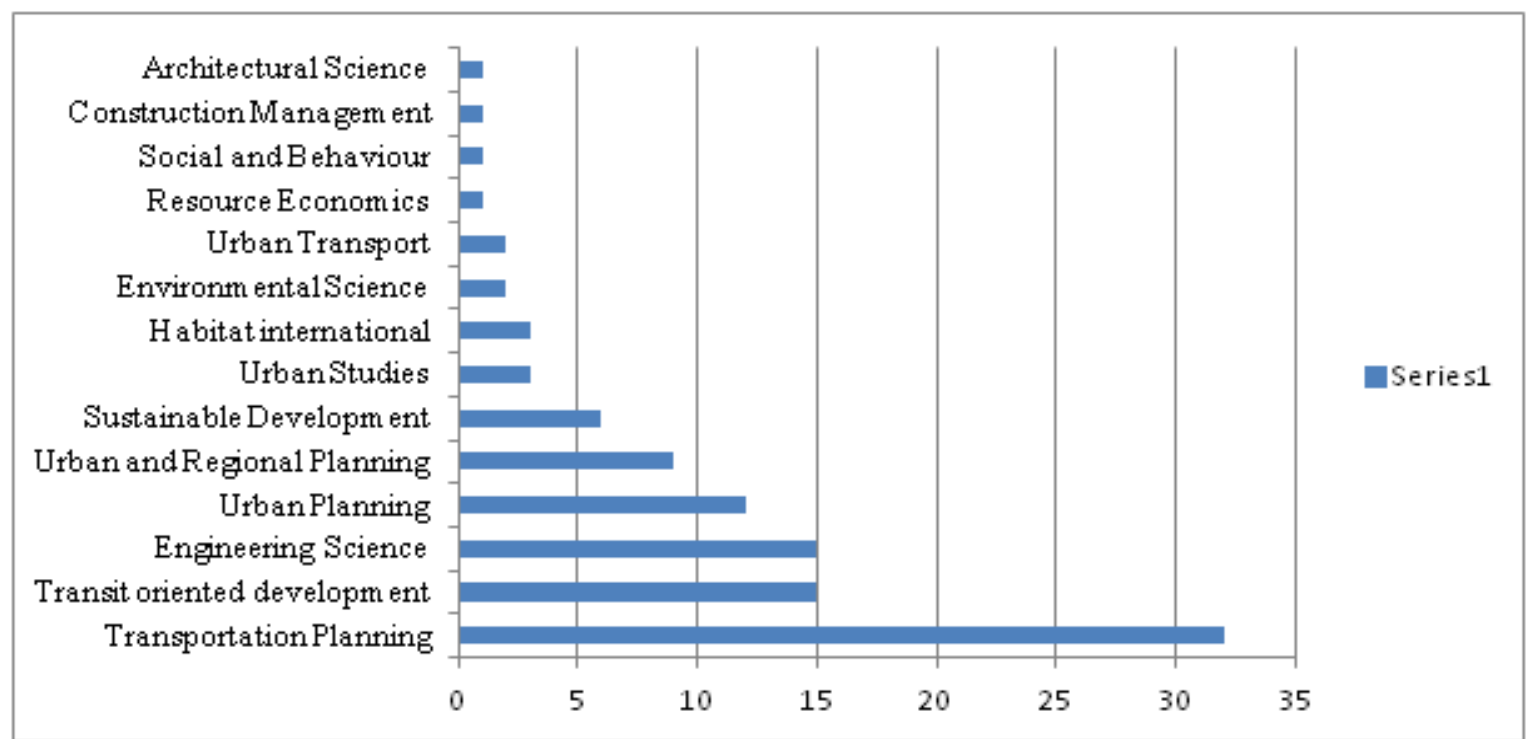

Figure 6. Number of papers for each area as per the journal in the corpus.

\section{CATALOGUING OF THE PAPERS}

To answer to Q1, Q2 and Q3, an organization of the publications was conducted based on the main topics addressed. During this process each paper was reviewed and inductively defines down list of topics. According to the topics defined, each paper was bifurcated which is reported in the Table 2.

Table 2. Bifurcation of the topics according to the own list in the paper corpus.

TOPICS

\begin{tabular}{|c|c|c|}
\hline Evolution TOD & $\begin{array}{l}\text { Papers related to this topic discusses about the development of } \\
\text { project in their particular 2egion according to the phases of growth. }\end{array}$ & $1,5,7,13,27$ \\
\hline Detail Analysis & $\begin{array}{l}\text { In this authors have given the detailed analysis of the development } \\
\text { of TOD between and after the execution of the project using } \\
\text { various tools and measuring criteria. }\end{array}$ & $\begin{array}{l}2,18,40,55,58,85,86,89,94 \\
97,99,101\end{array}$ \\
\hline $\begin{array}{l}\text { Sustainable } \\
\text { TOD }\end{array}$ & $\begin{array}{l}\text { This collection of papers includes the comparison of sustainability } \\
\text { and Transit Oriented Development as both the topics go hand in } \\
\text { hand. }\end{array}$ & $\begin{array}{l}3,8,21,22,41,51,52,62,72, \\
77,99\end{array}$ \\
\hline Challenges & $\begin{array}{l}\text { Various challenges faced during the execution and development of } \\
\text { the TOD projects are discussed such that it could kept in mind } \\
\text { while designing and TOD project. }\end{array}$ & $6,22,23,32,44$ \\
\hline Defining TOD & $\begin{array}{l}\text { Every author has its own definition of TOD as there is no standard } \\
\text { universal definition of TOD, therefore, it is very essential to } \\
\text { understand various definitions and explanation discussed by the } \\
\text { experts of TOD. }\end{array}$ & $\begin{array}{l}\text { 6, } 34,35,51,56,89,60,78,81 \\
82,92\end{array}$ \\
\hline $\begin{array}{l}\text { Implementation } \\
\text { strategies }\end{array}$ & $\begin{array}{l}\text { This topic includes various implementation strategies adopted by } \\
\text { various authors and practitioners all over the world to make Transit } \\
\text { Oriented Development a successful project. }\end{array}$ & $\begin{array}{l}8,19,25,28,29,30,34,43,47 \\
49,51,53,61,63,71,78,87, \\
88,94,98\end{array}$ \\
\hline $\begin{array}{l}\text { Assessment of } \\
\text { indicators }\end{array}$ & $\begin{array}{l}\text { To identify whether the TOD in any region is successful or not or } \\
\text { make a TOD successful, some parameters are required for the } \\
\text { justification which has been discussed in this section by various } \\
\text { authors. }\end{array}$ & $\begin{array}{l}9,12,14,17,21,37,38,39,50 \\
52,54,58,64,66,72,73,74, \\
77,79,84,85,86,87,88,90 \text {, } \\
91,95,96,97,101\end{array}$ \\
\hline Measuring TOD & $\begin{array}{l}\text { In this collection authors have measured various TOD's using their } \\
\text { own methodology and index to find out the reasons behind the } \\
\text { success and failures. }\end{array}$ & $\begin{array}{l}9,14,37,73,74,76,79,80,82 \\
83,84,85,86,87,88,89,90\end{array}$ \\
\hline Case study & $\begin{array}{l}\text { A variety of case studies have been analyzed and studied to make } \\
\text { the foundation more strong }\end{array}$ & $\begin{array}{l}10,17,18,19,20,31,32,33 \\
34,35,37,42,44,46,49,55, \\
56,61,65,66,68,69,81,102\end{array}$ \\
\hline Policy lessons & $\begin{array}{l}\text { In this authors have developed policy lessons for the successful } \\
\text { execution of TOD }\end{array}$ & $\begin{array}{l}11,47,63,71,75,81,92,93, \\
100\end{array}$ \\
\hline $\begin{array}{l}\text { Designing } \\
\text { Guidelines }\end{array}$ & $\begin{array}{l}\text { Similarly, designing guidelines have been identified and developed } \\
\text { by the authors required for their particular regions }\end{array}$ & $\begin{array}{l}15,30,31,36,43,45,65,71 \text {, } \\
75,83,100\end{array}$ \\
\hline Explanation & $\begin{array}{l}\text { Theory behind the need of TOD in present scenario has been } \\
\text { explained by various authors in this section. }\end{array}$ & 16,24 \\
\hline Modeling & $\begin{array}{l}\text { Here authors have developed different models for the quantitative } \\
\text { analysis for the execution and to check whether the TOD is } \\
\text { successful or a failure. }\end{array}$ & 39, 56, 59, 64, 66, 96, 101 \\
\hline
\end{tabular}

Figure 7 exhibits the occurrence of the various topics as they appeared in the papers. The four most often concentrated topics are:

\section{PAPERS}

$2,18,40,55,58,85,86,89,94$

$3,8,21,22,41,51,52,62,72$, 6, 22, 23, 32, 44, 50, 91

$6,34,35,51,56,89,60,78,81$, $8,19,25,28,29,30,34,43,47$, $49,51,53,61,63,71,78,87$, $88,94,98$ $91,95,96,97,101$

$9,14,37,73,74,76,79,80,82$, $10,17,18,19,20,31,32,33$, $34,35,37,42,44,46,49,55$, $56,61,65,66,68,69,81,102$

$11,47,63,71,75,81,92,93$ $15,30,31,36,43,45,65,71$, $75,83,100$

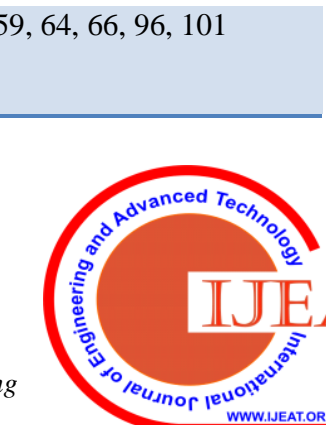




\section{A Systematic Literature on Application of Transit Oriented Development}

1. Assessment of indicators: To identify whether the TOD in any region is successful or not or make a TOD successful, some parameters are required for the justification which has been discussed in this section by various authors.

2. Case study: A variety of case studies have been analyzed and studied to make the foundation more strong
3. Implementation strategies: This topic includes various implementation strategies adopted by various authors and practitioners all over the world to make Transit Oriented Development a successful project.

4. Measuring TOD: In this collection authors have measured various TOD's using their own methodology and index to find out the reasons behind the success and failures.

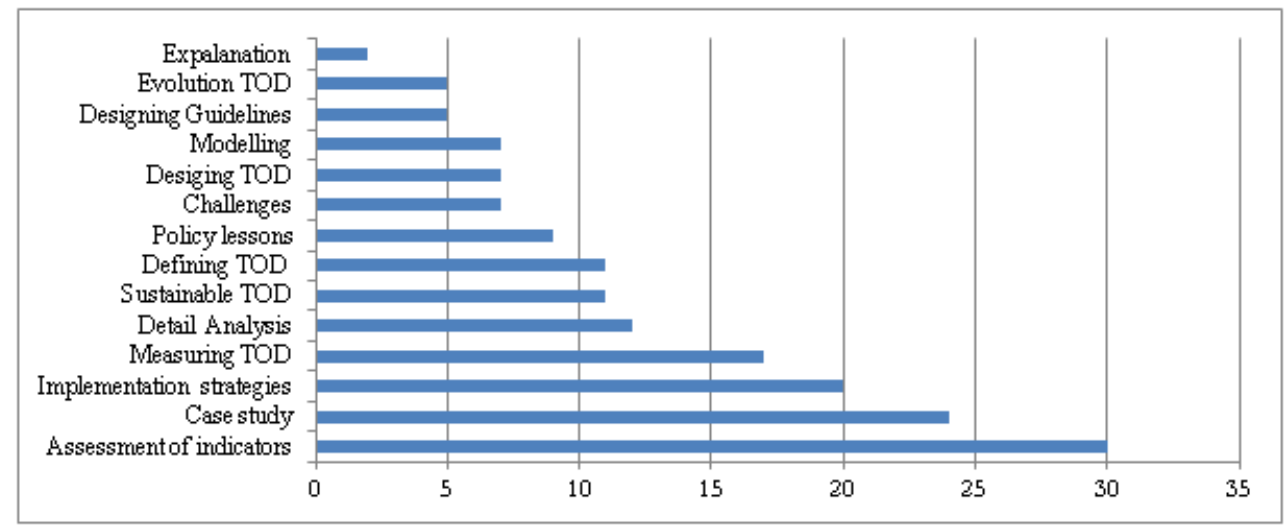

Figure 7. Number of papers concentrating on each area.

Note: Each paper may be listed to more than one topic

Table 3 give a detail analyses of methodologies and parameters for the application of transit oriented development studied in literature by various authors i.e., finally the answer of the Q2. Success or failure can be measured only when final step is known to us. Since stakeholders in this project might have different perspective, objectives as well as criteria for assessment, hence, this will also differ.
Whereas for the answer of Q3, no study has been found where TOD has been executed but TOD has been planned for many cities like Ahmadabad, Chennai and presently Delhi where criteria has been set by Delhi Development Authority and various other ones including the criteria of mixed use and compact development as per the typical which needs to be revised because as said by Kamruzzaman Md. Et. all (2014) that the reasons behind the failure of TOD are "development oriented transit" and "one - size fits all".

Table 3. TOD assessment by various authors

\begin{tabular}{|ll|}
\hline References & Methodologies/ Parameters \\
\hline Renne (2009) & $\begin{array}{l}\text { Assessing the achievement of TOD relies upon the vision of the } \\
\text { stakeholders. Thus, the Regional Performance Approach (RPA) and } \\
\text { Community Performance Approach (CPA) were his suggestions. }\end{array}$ \\
\hline Renne and Wells (2005) & $\begin{array}{l}\text { Developed a strategy to measure TOD including } 10 \text { best indicators are } \\
\text { identified that can monitor also. These are: Transit ridership; Density of } \\
\text { development; Quantity of streetscape; Quantity of mixed use development; } \\
\text { Pedestrian activity and safety; Increase in property value; Increase in tax } \\
\text { revenue; Public perception; Number of mode connections at the station/ stop; } \\
\text { and Parking. }\end{array}$ \\
\hline Nelson and Niles (2009) & $\begin{array}{l}\text { Acknowledged and counted } 16 \text { features that could conclude the attainment of } \\
\text { TOD at both levels of local and regional. They developed a concept called } \\
\text { 'Back casting Delphi' which can be utilized to know the perfect measure for } \\
\text { preferred TOD result. }\end{array}$ \\
\hline Belzer and Autler (2002) & $\begin{array}{l}\text { Functional outcomes were desired in TOD in comparison to substantial } \\
\text { characteristics. Six key criteria listed: Location efficiency; Choice; Value } \\
\text { capture; Financial return; Livability; and Efficient land use patterns at } \\
\text { regional level. }\end{array}$ \\
\hline Similar to the above mentioned "Belzer and Autler" criteria keeping in mind \\
that these criteria require a lot of data for the scrutiny.
\end{tabular}

Evaluated from Singh (2015) 


\section{CALCULATED ASSESSMENT PROCESS FOR EVALUATING SUCCESS OF TOD WITH CRITERIA AND INDICATORS}

A lot many studies have been acknowledged by numerous authors, categorizing the pointers to estimate the success of TOD in any area. Thus, rendering from the literature above, six main criteria and succeeding indicators have been computed which gives a supplementary meaning, to measure TOD such that they cover the different features of TOD. Thus, the lists of criteria are listed below which would be used for quantifying the success of TOD in Indian studies.

$\begin{aligned} \text { i. } & \text { Institutional Support } \\ \text { ii. } & \text { Quality of Cityscape } \\ \text { iii. } & \text { Health, Safety and Environment } \\ \text { iv. } & \text { Economic Development } \\ \text { v. } & \text { Travel Behavior } \\ \text { vi. } & \text { Socio- Cultural Impact }\end{aligned}$

Thus, the table below explains the validation behind the credentials of criteria as well as the indicators premeditated from the corpus of 102 papers.

Table 4. Listing of criteria based on paper corpus

\begin{tabular}{|c|c|c|c|c|c|c|c|c|c|c|c|c|c|c|}
\hline ASSESSMENT & \multicolumn{14}{|c|}{ PAPERS } \\
\hline INDICATORS & 6 & 9 & 14 & 37 & 38 & 54 & 58 & 64 & 72 & 73 & 74 & 80 & 86 & 101 \\
\hline Institutional support & $\mathrm{X}$ & $\sqrt{ }$ & $\mathrm{X}$ & $\mathrm{X}$ & $X$ & $\mathrm{X}$ & $\mathrm{X}$ & $\sqrt{ }$ & $\sqrt{ }$ & $\mathrm{X}$ & $\mathrm{X}$ & $\mathrm{X}$ & $\mathrm{X}$ & $\mathrm{X}$ \\
\hline Quality of cityscape & $\sqrt{ }$ & $\sqrt{ }$ & $\sqrt{ }$ & $\sqrt{ }$ & $\sqrt{ }$ & $\sqrt{ }$ & $\sqrt{ }$ & $\sqrt{ }$ & $\mathrm{X}$ & $\sqrt{ }$ & $\sqrt{ }$ & $\sqrt{ }$ & $\sqrt{ }$ & $\sqrt{ }$ \\
\hline $\begin{array}{l}\text { Health safety and } \\
\text { environment }\end{array}$ & $\sqrt{ }$ & $\sqrt{ }$ & $\sqrt{ }$ & $\sqrt{ }$ & $\mathrm{X}$ & $\sqrt{ }$ & $\sqrt{ }$ & $\sqrt{ }$ & $\sqrt{ }$ & $\sqrt{ }$ & $\sqrt{ }$ & $\sqrt{ }$ & $\sqrt{ }$ & $\sqrt{ }$ \\
\hline $\begin{array}{l}\text { Economic } \\
\text { development }\end{array}$ & $\sqrt{ }$ & $\sqrt{ }$ & $\sqrt{ }$ & $\sqrt{ }$ & $\sqrt{ }$ & $\sqrt{ }$ & $\sqrt{ }$ & $\sqrt{ }$ & $\sqrt{ }$ & $\sqrt{ }$ & $\sqrt{ }$ & $\sqrt{ }$ & $\sqrt{ }$ & $\mathrm{X}$ \\
\hline Travel behavior & $\sqrt{ }$ & $\mathrm{X}$ & $\sqrt{ }$ & $\sqrt{ }$ & $\sqrt{ }$ & $\sqrt{ }$ & $\sqrt{ }$ & $\sqrt{ }$ & $\sqrt{ }$ & $\sqrt{ }$ & $\sqrt{ }$ & $\sqrt{ }$ & $\sqrt{ }$ & $\sqrt{ }$ \\
\hline Socio- cultural impact & $\mathrm{X}$ & $\mathrm{X}$ & $\mathrm{X}$ & $\mathrm{X}$ & $\sqrt{ }$ & $\mathrm{X}$ & $\mathrm{X}$ & $\sqrt{ }$ & $\sqrt{ }$ & $\sqrt{ }$ & $\mathrm{X}$ & $\mathrm{X}$ & $\mathrm{X}$ & $\mathrm{X}$ \\
\hline
\end{tabular}

\section{RESEARCH METHODOLOGIES EMPLOYED} AND ITS CORRELATION

To categorize the study methodologies, the scrutiny followed an inductive approach similar to the one previously discussed. Each paper is classified on own experiences. Then, a table was created by revising and grouping the various methodologies identified.

Table 5. Division of the topics according to the methodology adopted

\begin{tabular}{|l|l|}
\multicolumn{2}{|c}{ Table 5. Division of the topics according to the methodology adopted } \\
\hline & Papers \\
\hline Methods & $9,10,12,14,15,16,17,20,22,32,33,34,35,40,41,42,43,44,46,47$, \\
\hline Case Study/ Intreview & $52,55,72$ \\
\hline Quantitative Modelling & $8,18,19,21,27,29,40,48,72,73,84,85,86$ \\
\hline & $5,24,25,26,27,28,37,38,39,49,50,52,56,57,58,63,65,66,67,72$, \\
\hline Questionaire/ Survey & $74,75,78,80,81,82,84,85,86,90$ \\
\hline Experimental/ Piloting & $1,18,30,36$ \\
\hline & $3,4,6,7,11,13,14,16,19,23,28,29,31,32,33,34,35,37,38,39,51$, \\
\hline Literature/Systematic review & $54, .55,60,61,62,63,64,68,69,70,71,72,76,77,78,79,80,81,83,86$ \\
\hline Simulation & $88,89,90,91,92,93,94,95,100,102$ \\
\hline
\end{tabular}

The resulting classification is reported in Figure8 and Table 5, where each paper could adopt more than one methodology. In this papers are characterized according to the methodologies used by the authors in their respective researches. It can be concluded that a systematic literature review is majorly utilized by the researchers to work for transit oriented development. 


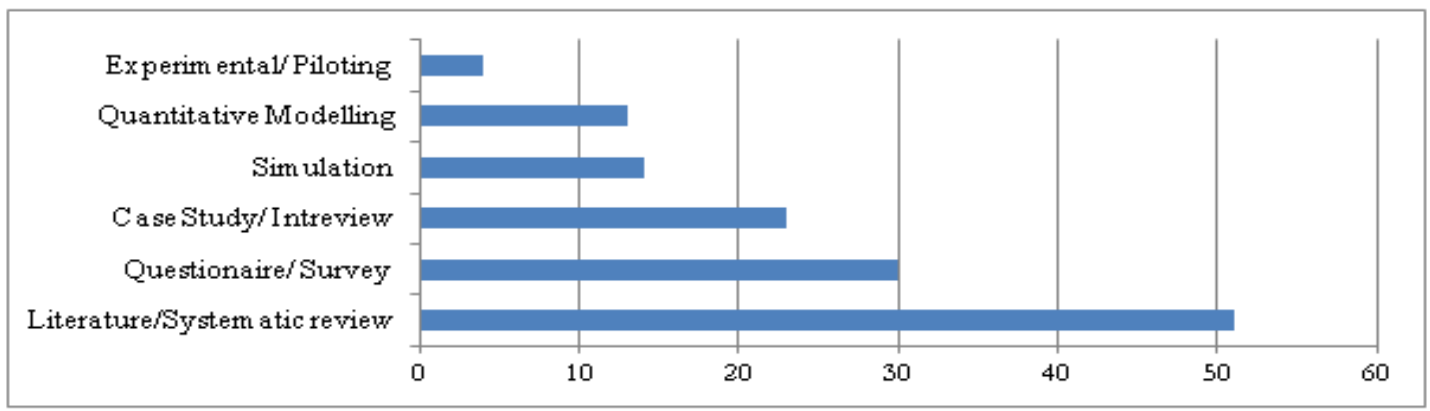

Figure 8. Number of papers according to the method in the corpus.

To understand more, the type of data collected and used in the study is also bifurcated. Therefore, the analysis distinguished between qualitative, quantitative data and the papers using both techniques. Quantitative data can be quantified and verified and are amendable to statistical manipulation whereas qualitative data is achieved from the case studies and interviews, which cannot be measured directly. The results of the classification of data are reported in Figure9.

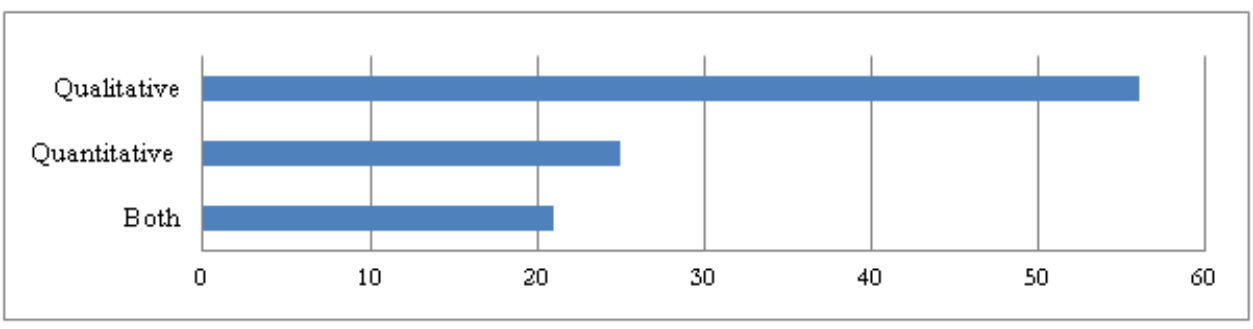

Figure 9. Variety of data utilized in the corpus.

\section{RESULT ANALYSIS: ISSUES, GAPS AND FUTURE LINES OF RESEARCH}

In addition to answering the four research questions, the scrutiny of the literature on application of transit oriented development permitted us to classify some guidelines for research that deserve further exploration by both academics and practitioners.

Likewise, from above discussion it is clear that TOD has been defined diversely by various authors which explain that there is no standard definition of TOD. It is expected that the main idea of TOD is the integration land use and transit to encouraged to use public transport more and avoid using personal vehicles, they are even encouraged to be pedestrianism or use non- motorized transport to make environment more sustainable. Stakeholders and involved parties have different criteria for developing TOD and hence have different aims and definitions.

Since, all authors define TOD diversely but there is not much difference in their definitions. Therefore, majorly the benefits expected to be out of each TOD are:

1. Increased use of public transport, thus bringing more prospects.

2. Increasing property values and healthy market competition leading to financial and economic development.

3. Making people pedestrianism or use nonmotorized transport, to create healthy environment.

4. Avoid congestion on roads and create a healthy lifestyle, safer vicinity and active societies.

5. Utilization of land in a more organized and systematic order.

6. Increase transit ridership and diminish traffic pollution, utilization of non renewable resources.

Detail analysis of the aforementioned, it is quite clear that Transit Oriented Development concept cannot only be achieved by creating a area with higher densities with mixed land use or by pedestranizing them alone. Regions including all these characteristics with appropriate access to a good transit system still require integration of land use and transit system.

Whereas Singh (2015) declared that public reserves in facilities such as for TOD are made often without knowing present circumstances and probable results of the proposals. A deficiency of inclusive tools to eveluate TOD or TODness of any area is identified in Wells and Renne in 2005. Whereas there are many indicators to measure TOD, but in no case indicators are used to quantify TOD jointly but the case studies were mainly qualitative discussions by authors. Assessment of TOD- ness will add in evaluating TOD projects also (Evans and Pratt, 2007).

\section{CONCLUSION}

The intention was to provide a systematic analysis of the scientific literature that addresses the importance of the concept of Transit Oriented Development which is degrading day by day. There is significant confirmation that enthusiasm for transit oriented development is on the ascent in the United States. Transit Oriented-Development moves the concentration from diffuse, car sited development to denser, blended utilizes neighborhoods revolved around travel station. TOD can have a heap of social, natural and financial advantages for individuals and groups, from lessened expenses of living, better access to employments, and financial development, to more beneficial ways of life and, through diminished car utilize that defines the rationale of TOD in India.

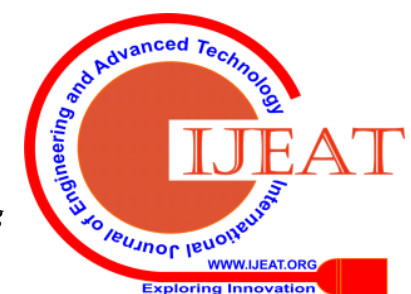


Therefore, the objective of this literature review is to be aware of the genesis of the literature and put forward idea regarding the best steps for further research. Furthermore, a lot many methodologies have been adopted to study these topics where year wise bifurcation, methodological investigation, etc have applied. Hopefully, this research will help the academics and practitioners to know TOD concept and help them to get used to their efforts in a way that is consistent with past progress and future point of view.

\section{REFERENCES}

1. Arrington, G. B. (2009). Portland's TOD evolution: from planning to lifestyle. Transit Oriented Development: Making it Happen, 109-124.

2. Atkinson-Palombo, C., \& Kuby, M. J. (2011). The geography of advance transit-oriented development in metropolitan Phoenix, Arizona, 2000-2007. Journal of Transport Geography, 19(2), 189-199.

3. Azra, N. (2016), "Transit Oriented Development (TOD) - A Road towards Sustainable Transportation”, South Asian Journal of Research in Engineering Science and Technology (SAJREST), Volume: 01 Issue: 03, pg. no. 360-368.

4. Bajracharya, B., Khan, S., \& Longland, M. (2005). Regulatory and incentive mechanisms to implement transit oriented development (TOD) in South East Queensland. ERA-Humanities and Creative Arts, 219.

5. Balz, V., \& Schrijnen, J. (2009). From concept to projects: Stedenbaan, the Netherlands. Transit Oriented Development: Making It Happen, 75 90 .

6. Belzer, D., \& Autler, G. (2002). Transit oriented development: Moving from rhetoric to reality (pp. 06-15). Washington, DC: Brookings Institution Center on Urban and Metropolitan Policy.

7. Bernick, M., \& Cervero, R. (1997). Transit villages in the 21st century.

8. Bertolini, L., Curtis, C., \& Renne, J. L. (2009). TODs for a sustainable future: key principles to make TOD happen'.

9. Black, J., Tara, K., \& Pakzad, P. (2016). Planning and Design Elements for Transit Oriented Developments/Smart Cities: Examples of Cultural Borrowings. Procedia Engineering, 142, 2-9.

10. Boarnet, M. G., \& Compin, N. S. (1996). Transit-oriented development in San Diego County: Incrementally implementing a comprehensive idea. University of California Transportation Center.

11. Boarnet, M., \& Crane, R. (1997). LA story: A reality check for transitbased housing. Journal of the American Planning Association, 63(2), 189-204.

12. Boarnet, M. G., \& Crane, R. (1998). Public finance and transit-oriented planning: New evidence from southern California. Journal of Planning Education and Research, 17(3), 206-219.

13. Boarnet, M. G., \& Sarmiento, S. (1998). Can land-use policy really affect travel behaviour? A study of the link between non-work travel and land-use characteristics. Urban Studies, 35(7), 1155-1169.

14. Borg, M., \& Orsini, R. (2008). Transit oriented developmentintegrating land-use and transport in small island states. Urban Transport XIV: Urban Transport and the Environment in the 21st Century, 14, 457.

15. Calthrope Associates (1992), "City of San Diego land guidance system, transit- oriented development design guidelines. The city of San Diego, Planning Department", Office of the City Architect, 533-4500. Retrieved from: $<$ https://www.sandiego.gov/sites/default/files/legacy/planning/docume nts/pdf/trans/todguide.pdf $>$.

16. Calthorpe, P. (1993). The next American metropolis: Ecology, community, and the American dream. Princeton architectural press.

17. Chan, N. W., Nakamura, A., \& Imura, H. Transit-Oriented Development (TOD).

18. Cervero, R., \& Kockelman, K. (1997). Travel demand and the 3Ds: density, diversity, and design. Transportation Research Part D: Transport and Environment, 2(3), 199-219.

19. Cervero, R. (2004). Transit-oriented development in the United States: Experiences, challenges, and prospects (Vol. 102). Transportation Research Board.

20. Cervero, R. (2006). Public Transport and Sustainable Urbanism: Global Lesson. University of California Transportation Center.

21. Cervero, R., \& Sullivan, C. (2010). Toward Green TODs. Institute of Transportation Studies, University of California, Berkeley.

22. Suzuki, H., Cervero, R., \& Iuchi, K. (2013). Transforming cities with transit: Transit and land-use integration for sustainable urban development. World Bank Publications.
23. Cervero, R. (2014). Transport Infrastructure and the Environment in the Global South: Sustainable Mobility and Urbanism. Journal Perencanaan Wilayah dan Kota, 25(3), 174-191.

24. America, R. (2007). Why Transit-oriented Development and why Now? Reconnecting America.

25. CTOD (2010), "Creating Successful Transit-Oriented Districts in Los Angeles", The Center for Transit-Oriented Development Creating Successful Transit-Oriented Districts in Los Angeles.

26. Thorne-Lyman, A., Wood, J., Zimbabwe, S., Belzer, D., Breznau, N., Brennan, T., \& Yake, C. (2011). Transit-Oriented Development Strategic Plan. Center on Transit-Oriented Development.

27. Curtis, C. (2008). Evolution of the transit-oriented development model for low-density cities: a case study of Perth's new railway corridor. Planning, Practice \& Research, 23(3), 285-302.

28. Curtis, C. (2009). Implementing transit oriented development through regional plans: a case study of Western Australia.

29. Curtis, C. (2012). Delivering the'D'in transit-oriented development: Examining the town planning challenge. Journal of Transport and Land Use, 5(3).

30. Delhi Development Authority, New Delhi (2010), "Transit Oriented Development (TOD)- Policy and Implementation Framework", Delhi Development Authority, New Delhi.

31. Dittmar, H., \& Ohland, G. (Eds.). (2012). the new transit town: best practices in transit-oriented development. Island Press.

32. Dorsey, B., \& Mulder, A. (2013). Planning, place-making and building consensus for transit-oriented development: Ogden, Utah case study. Journal of Transport Geography, 32, 65-76.

33. Doulet, J. F., Delpirou, A., \& Delaunay, T. (2016). Taking advantage of a historic opportunity? A critical review of the literature on TOD in China. Journal of Transport and Land Use, 10(1).

34. Dragutescu, A. E. (2006). A different perspective of planning: transitoriented development (Doctoral dissertation, University of Porto Porto).

35. Evans, J. E., Pratt, R. H., Stryker, A., \& Kuzmyak, J. R. (2007). Traveler response to transportation system changes: Chapter 17transit oriented development (TCRP Report 95). Washington, DC: Transportation Research Board.

36. Ewing, R., \& Cervero, R. (2010). Travel and the built environment: a meta-analysis. Journal of the American planning association, 76(3), 265-294.

37. FARD, P. (2013). Measuring Transit Oriented Development.

38. Galelo, A., Ribeiro, A., \& Martinez, L. M. (2014). Measuring and Evaluating the Impacts of TOD Measures-Searching for Evidence of TOD Characteristics in Azambuja Train Line. Procedia-Social and Behavioral Sciences, 111, 899-908.

39. Grigolona, A., Singh, Y.J., Koevaa, M. and Madureiraa, M. (2016), "Transit-Oriented Development (TOD) Assessment Using 3d Visualisation and Modelling," DDSS.

40. Guthrie, A., \& Fan, Y. (2016). Developers' perspectives on transitoriented development. Transport Policy, 51, 103-114.

41. Hasibuan, H. S., Soemardi, T. P., Koestoer, R., \& Moersidik, S. (2014). The role of transit oriented development in constructing urban environment sustainability, the case of Jabodetabek, Indonesia. Procedia Environmental Sciences, 20, 622-631.

42. Hoffman. (2006), "Transit: Can it sustain TOD?" The Mission Group.

43. Howe, A., Glass, G., \& Curtis, C. (2009). Retrofitting TOD and managing the impacts: the case of Subi Centro.

44. Hutton, C. (2011). Transit-oriented Development Case Study Policy Analysis: A Comparative Study of Programs and Policies across the United States (Doctoral dissertation, University of Florida).

45. Rahmat, A., Endot, I. R., Ahmad, Z., Ishak, Z., \& Ibrahim, C. K. I. Development Of Transit Oriented Development (TOD) Model For Malaysia.

46. Jacobson, J., \& Forsyth, A. (2008). Seven American TODs: Good practices for urban design in transit-oriented development projects. Journal of Transport and Land Use, 1(2).

47. Jackson, S. (2014), "Transit-Oriented Development (TOD) ProgramStrategic Plan update", Sound Transit, Seattle.

48. Kamruzzaman, M., Baker, D., Washington, S., \& Turrell, G. (2014) Advance transit oriented development typology: case study in Brisbane, Australia. Journal of Transport Geography, 34, 54-70.

49. Kelly, M., Bose, R., \& Bose, S. (2014). Transit Oriented Development (TOD), a Comprehensive Alternative to a Public Transport Based Development, Case Study New Delhi. In European Transport Conference 2014. 
50. Keshkamat, S. S., Looijen, J. M., \& Zuidgeest, M. H. P. (2009). The formulation and evaluation of transport route planning alternatives: a spatial decision support system for the Via Baltica project, Poland. Journal of Transport Geography, 17(1), 54-64.

51. Li, C. N., \& Lai, T. Y. (2006). Sustainable Development and TransitOriented Development Cities in Taiwan. In The 12th Annual International Sustainable Development Research Conference.

52. Lila, A.M.H. (2014), "Transit Oriented Development (TOD) As A Holistic Approach for Future Urbanism in Egypt", 10th International Conference, "Role of Engineering towards A Better Environment" Alexandria University.

53. Lima, F., \& Montenegro, N. (2016). Computational Approach for the Assessment of Transit Oriented Development Principles-A multivariate optimization method for urban planning.

54. Lukman, A. (2014) "Development and implementation of transit oriented development (TOD) Index around the current transit nodes", (M.Sc. Thesis) University of Twente faculty of Geo- Information and Earth observation (ITC), Enschede.

55. Van Lierop, D., Maat, K., \& El-Geneidy, A. (2017). Talking TOD: learning about transit-oriented development in the United States, Canada, and the Netherlands. Journal of Urbanism: International Research on Place making and Urban Sustainability, 10(1), 49-62.

56. Masoumi, H. E., \& Mirmoghtadaee, M. (2016). Editorial Preface. Transit-Oriented Development in Iran: Challenges and Solutions. TeMA Journal of Land Use, Mobility and Environment, 2-4.

57. Muley, D. S., Bunker, J. M., \& Ferreira, L. (2007). Evaluating transit quality of service for transit oriented development (TOD).

58. Nakamura, K., Fumei, G. U., Wasuntarasook, V., Vichiensan, V., \& Hayashi, Y. (2016). Failure of Transit-Oriented Development in Bangkok from a Quality of Life Perspective. Asian Transport Studies, 4(1), 194-209.

59. Nasri, A., \& Zhang, L. (2014). The analysis of transit-oriented development (TOD) in Washington, DC and Baltimore metropolitan areas. Transport policy, 32, 172-179.

60. Nelson, D., Niles, J., \& Hibshoosh, A. (2001). A new planning template for transit-oriented development (Vol. 1). Mineta Transportation Institute, San José State University.

61. Newman, P. (2005). Transit-Oriented Development: An Australian Overview. Transit Oriented Development-Making it Happen.

62. Newman, P., \& Kenworthy, J. (2007). Greening urban transportation.

63. Newman, P. (2009). Planning for transient oriented development: strategic principles.

64. Niles, J., \& Nelson, D. (1999, April). Measuring the Success of Transit-Oriented Development. In Retail Market Dynamics and Other Key Determinants, Prepared for the American Planning Association National Planning Conference, Seattle, Washington, April (pp. 24-28).

65. Papa, E., \& Bertolini, L. (2015). Accessibility and transit-oriented development in European metropolitan areas. Journal of Transport Geography, 47, 70-83.

66. Pelzer, P. (2015). Usefulness of Planning Support Systems. Conceptual perspectives and practitioners' experiences. $\mathrm{PhD}$ Series InPlanning, book, 3.

67. Petkar, A. S., \& Hamand, S. S. (2013). A Study of Transit Oriented Development in Indian Context.

68. Pojani, D., \& Stead, D. (2014). Ideas, interests, and institutions: explaining Dutch transit-oriented development challenges. Environment and Planning A, 46(10), 2401-2418.

69. Pojani, D., \& Stead, D. (2015). Transit-Oriented Design in the Netherlands. Journal of Planning Education and Research, 35(2), 131144.

70. Qviström, M., \& Bengtsson, J. (2015). What kind of transit-oriented development? Using planning history to differentiate a model for sustainable development. European Planning Studies, 23(12), 25162534.

71. District, R. T. (2010). Strategic plan for transit oriented development. Adopted by RTD Board of Directors on September, 21.

72. Renne, J. L. (2009). Evaluating transit-oriented development using a sustainability framework: Lessons from Perth's network city. Planning Sustainable Communities: Diversity of Approaches and Implementation Challenges. Ed. Sasha Tsenkova. Calgary: University of Calgary, 115-148.

73. Renne, J. L. (2007). Measuring the performance of transit-oriented developments in Western Australia. Victoria Transport Policy Institute.

74. Renne, J. L., \& Wells, J. S. (2005). Transit-oriented development: Developing a strategy to measure success (No. 294). Transportation Research Board.

75. Renne, J. L. (2008). Smart growth and transit-oriented development at the state level: Lessons from California, New Jersey, and Western Australia. Journal of Public Transportation, 11(3), 5.
76. Renne, J. L. (2007). Measuring the success of transit-oriented development using a sustainability framework: TOD outcome analysis. Urban Sustainability through Environmental Design: Approaches to Time-People-Place Responsive Urban Spaces, 106.

77. Renne, J. L. (2009). Evaluating transit-oriented development using a sustainability framework: Lessons from Perth's network city. Planning Sustainable Communities: Diversity of Approaches and Implementation Challenges. Ed. Sasha Tsenkova. Calgary: University of Calgary, 115-148.

78. Rose, J. Companies. (2013), "Making It Happen: Opportunities and Strategies for Transit-Oriented Development In Knowledge Corridor", Capitol Region Council of Governments Pioneer Valley Planning Commission.

79. Schlossberg, M., \& Brown, N. (2004). Comparing transit-oriented development sites by walkability indicators. Transportation Research Record: Journal of the transportation research board, (1887), 34-42.

80. Sharma, A. (2016). A framework for assessing feasibility of TransitOriented Development (TOD) project sites (Doctoral dissertation, Colorado State University. Libraries).

81. Shastry, S. (2010). Spatial assessment of transit oriented developmen in Ahmadabad, India (Master's thesis, University of Twente).

82. Shinkle, D. (2012). Transit-oriented development in the states.

83. Singh, Y. J., Zuidgeest, M. H. P., Flacke, J., \& van Maarseveen, M. F. A. M. (2012). A design framework for measuring transit oriented development. WIT Transactions on The Built Environment, 128, 719730.

84. Singh, Y. J., Fard, P., Zuidgeest, M., Brussel, M., \& van Maarseveen, M. (2014). Measuring transit oriented development: a spatial multi criteria assessment approach for the City Region Arnhem and Nijmegen. Journal of Transport Geography, 35, 130-143.

85. Singh, Y. J., He, P., Flacke, J., \& van Maarseveen, M. Measuring Transit Oriented Development Over A Region Using an Index.

86. Singh, Y.J. (2015), Measuring Transit Oriented Development (TOD) at Regional and Local Scales, A Planning Support Tool, Thesis at University of Twente.

87. Singh, Y. J., Lukman, A., He, P., Flacke, J., \& Zuidgeest, M. (2015). Planning for Transit Oriented Development (TOD) using a TOD index. Planning, 15, 2132

88. Singh, Y. J., He, P., Flacke, J., \& Van Maarseveen, M. F. A. M. Measuring TOD Over A Region Using GIS Based Multiple Criteria Assessment Tools.

89. Singh, Y. J., Lukman, A., Flacke, J., Zuidgeest, M., \& Van Maarseveen, M. F. A. M. (2017). Measuring TOD around transit nodes-Towards TOD policy. Transport Policy, 56, 96-111.

90. Taki, H. M., Maatouk, M. M. H., Qurnfulah, E. M., \& Aljoufie, M. O. (2017). Planning TOD with land use and transport integration: a review. Journal of Geoscience, Engineering, Environment, and Technology, 2(1), 84-94.

91. Bertolini, L., \& Tan, W. (2010). Barriers to Transit Oriented Developments in the Netherlands: A luxury problem. In 24th AESOP Annual Conference. Helsinki, Finland: AESOP.

92. Transit, C. Transit Oriented Development Best Practices Handbook.

93. The City of Calgary. (2006), "Transit Friendly Design Guide: Calgary Transit", Calgary Transit Division Transportation Department.

94. Thomas, R., \& Bertolini, L. (2015). Defining critical success factors in TOD implementation using rough set analysis. Journal of Transport and Land Use, 10(1).

95. Vale, D. S. (2015). Transit-oriented development, integration of land use and transport, and pedestrian accessibility: Combining node-place model with pedestrian shed ratio to evaluate and classify station areas in Lisbon. Journal of transport geography, 45, 70-80.

96. Vijayalakshmi, M. (2009). Transit oriented land use development of northern suburban rail corridor in Chennai a systems approach.

97. Wey, W. M., \& Chiu, Y. H. (2013). Assessing the walkability of pedestrian environment under the transit-oriented development. Habitat International, 38, 106-118.

98. Wey, W. M. (2015). Smart growth and transit-oriented development planning in site selection for a new metro transit station in Taipei, Taiwan. Habitat International, 47, 158-168.

99. Wey, W. M., Zhang, H., \& Chang, Y. J. (2016). Alternative transitoriented development evaluation in sustainable built environment planning. Habitat International, 55, 109-123. 
100. Yang, P. P. J., \& Lew, S. H. (2009). An Asian model of TOD: The planning integration in Singapore. Transit-Oriented Development: Making it Happen, edited by C. Curtis, JL Renne, and L. Bertolini, 91109.

101. Zhang, Y., \& Guindon, B. (2006). Using satellite remote sensing to survey transport-related urban sustainability: Part 1: Methodologies for indicator quantification. International Journal of Applied Earth Observation and Geo information, 8(3), 149-164.

102. Zhang, Y. (2011). The role of transit-oriented development in urban planning of cities in China (Doctoral dissertation, University of Florida)

\section{FURTHER READING}

1. Nguyen Quang Minh (2016) "Application of "Car-Free City" and "City of Short Walks" to Living Quarters in Hanoi Towards Sustainable Mobility and Logistics", Science Direct, Pg. No. 284-291.

2. KazukiAkamura, Furnei Gu, VasineeWasuntarasook, VaramethVichiensan and YoshitsugnHayanshi (2016) "Failure of Transit Oriented Development in Bangkok from a Quality of Life", Asian Transport Studies, Vol.1, Pg. No. 194- 209.

3. Ghim Ping ONG, Kumares C. Sinha, Tein Fang FWA (2010),,"Strategies through achieving Sustainability through Integral Transportation \& Urban development in USA \& Asia", Asian Transport Studies, Vol.1 Pg. No. 89-104.

4. Monyrath KOV, Daisuke Fukuda, Tetsuo Yai(2011),, "Optimizing Frequency of Bus Services in Mixed Traffic Urban Streets", Asian Transport Studies, Vol.1 Pg. No. 352-367.

\section{AUTHORS PROFILE}

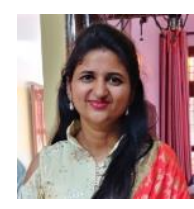

Ar. Deepshikha Jain is an Architect- Planner with acute interest in sustainable growth of cities. She has completed her graduation in B. Arch in 2010 as well as her post-graduation in Urban and Rural Planning from DCRUST, Murthal, India in 2013. In these years, she has worked with organizations of Architects and Planners on Urban Planning projects and even done residential projects on her own. She has a vast experience of teaching with many institutions at Assistant as well as working as an Associate Professor at Hindu School of Architecture, Sonepat. In 2016, she started her PhD from Amity University, Noida and presently working on various National and International papers, conference papers and has participated in various courses and conferences, etc. She has been working as incharge on the various posts of Anti- ragging cell committee, NATA, NASA, etc. she loves to travel and explore new things, in- total loves to keep herself busy. She is a member of IIA and IIV also.

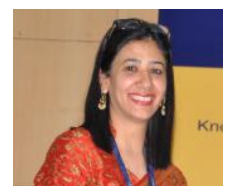

Prof. (Dr.) Ekta Singh- Currently Director Amity School of Design, Amity University Uttar Pradesh. She is an architect and has more than 19 years of experience in the consulting, education and research in the field of architecture and interior design. She has worked on numerous residential and office projects and has made remarkable intense contribution in the growth of the organizations of which she has been a part. She has numerous research papers to her credit in the international journals of repute. She was awarded the Mashav Scholarship by the State of Israel. She has been on various advisory posts on design projects, for many consulting firms and juror for many students' design competitions. Also, she is on Boards of Studies of State University and Moderation Boards of National Examinations. She has chaired many conferences, seminars and workshops on the topics of sustainability, research and design. She is very competent, result-oriented and energetic by nature. Her active involvement in the various human-value initiatives for the betterment of the youth power and community building allows her an opportunity to be connected with the various corners of the society. She is a live liver donor and intensely supports the campaign for the organ donation and leaves no scope for any opportunity of community and social welfare.

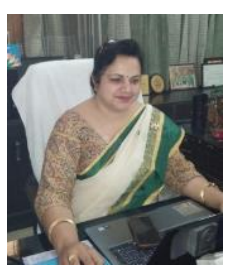

Prof. Dr. Rashmi Ashtt -Twenty seven years of experience in Architecture and Urban Planning, Dr. Rashmi Ashtt is considered an expert in the field work, Ph.D. in Urban Planning, she built her Professional qualifications further through several cutting edge National and International certification courses. Her industry experience includes senior positions with renowned organizations and on various City Development Plans. Her significant Research has been published in various journals all over the world. Currently she is The Director of Hindu College of Design, Architecture and Planning, Delhi NCR. She has won many awards including 'Proud to be an Indian Woman Award' by Saanwari Women Power Club, which was Presented to her by MLA and Parliament Secretary, Delhi. 